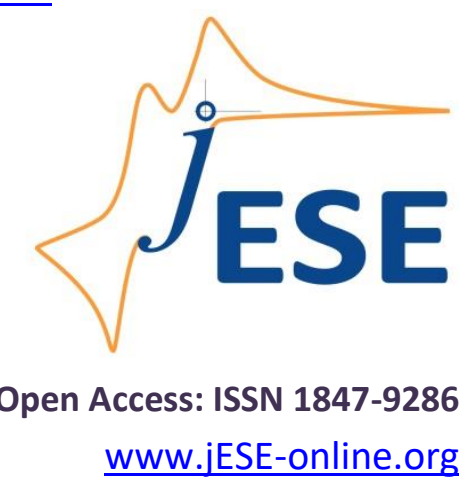

Original scientific paper

\title{
Study of oxygen evolution reaction on thermally prepared ${ }_{x} \mathrm{PtO}_{\mathrm{y}^{-}(100-\mathrm{x})} \mathrm{IrO}_{2}$ electrodes
}

\author{
Ollo Kambiré ${ }^{1, \bigotimes}$, Lemeyonouin A. G. Pohan ${ }^{2}$, Konan H. Kondro ${ }^{3}$ and \\ Lassiné Ouattara ${ }^{3, \text { : }}$ \\ ${ }^{1}$ UFR Sciences et Technologies, Université de Man, BP 20 Man, Côte d'Ivoire \\ ${ }^{2}$ UFR Sciences Biologiques, Université Peleforo Gon Coulibaly de Korhogo, BP 1328 Korhogo, Côte \\ d'Ivoire \\ ${ }^{3}$ Laboratoire de constitution et réaction de la matière, UFR SSMT, Université Félix Houphouët- \\ Boigny de Cocody, Abidjan, 22 BP 582 Abidjan 22, Côte d'Ivoire
}

Corresponding authors: ${ }^{\text {kambireollo@yahoo.fr; }}$ ouatlassine@yahoo.fr

Received: March 9, 2020; Revised: June 21, 2020; Accepted: July 10, 2020

\begin{abstract}
The mixed coupled ${ }_{x} \mathrm{PtO}_{y^{-}(100-x)} / \mathrm{rO}_{2}$ electrodes $(x=0,10,20,30,40,50,60,70,80,90$ and 100) were thermally prepared at $450^{\circ} \mathrm{C}$ on titanium supports. The prepared electrodes were firstly physically characterized by scanning electron microscopy (SEM), X-ray diffraction (XRD) and $X$-ray photoelectron spectroscopy (XPS). Afterwards, electrochemical characterizations were performed by voltammetric (cyclic and linear) methods in different electrolyte media (KOH and $\mathrm{HClO}_{4}$ ). It is shown that the prepared electrodes are composed by both PtO ${ }_{y}$ (platinum and platinum oxide) and $\mathrm{IrO}_{2}$ (iridium dioxide). For $\left.{ }_{x} \mathrm{PtO}_{y^{-}(100-x)}\right) \mathrm{rO}_{2}$ electrodes having higher content of $\mathrm{IrO}_{2}$, more surface cracks and pores are formed, defining a higher surface area with more active sites. Higher surface area due to presence of both $\mathrm{PtO}_{y}$ and $\mathrm{IrO}_{2}$, is for ${ }_{x} \mathrm{PtO}_{y^{-}}(100-$ $\left.{ }_{x}\right) \mathrm{IO}_{2}$ electrodes in $1 \mathrm{M} \mathrm{KOH}$ solution confirmed by cyclic voltammetry at potentials of the oxide layer region. For all prepared electrodes, voltammetric charges were found higher than for $\mathrm{PtO}_{y}$, while the highest voltammetric charge is observed for the mixed ${ }_{40} \mathrm{PtO}_{y-60} \mathrm{IrO}_{2}(x=40)$ electrode. The Tafel slopes for oxygen evolution reaction (OER) in either basic $(0.1 \mathrm{M} \mathrm{KOH})$ or acid $\left(0.1 \mathrm{M} \mathrm{HClO}_{4}\right)$ media were determined from measured linear voltammograms corrected for the ohmic drop. The values of Tafel slopes for OER at PtO ${ }_{y},{ }_{90} \mathrm{PtO}_{y^{-10}} \mathrm{IrO}_{2}$ and $\mathrm{IrO}_{2}$ in basic medium are 122, 55 and $40 \mathrm{mV} \mathrm{dec}{ }^{-1}$, respectively. For other mixed electrodes, Tafel slopes of $40 \mathrm{mV} \mathrm{dec}{ }^{-1}$ were obtained. Although proceeding by different OER mechanism, similar values of Tafel slopes were obtained in acid medium, i.e., Tafel slopes of 120, 60 and $39 \mathrm{mV} \mathrm{dec}^{-1}$ were obtained for $\mathrm{PtO}_{y},{ }_{90} \mathrm{PtO}_{y^{-}} \mathrm{IIO}_{2}$ and $\mathrm{IrO}_{2}$, and $40 \mathrm{mV} \mathrm{dec}{ }^{-1}$ for other mixed electrodes. The analysis of Tafel slope values showed that OER is more rapid on coupled mixed electrodes than on pure $\mathrm{PtO}_{y}$. For mixed ${ }_{x} \mathrm{PtO}_{y^{-}(100-\mathrm{x})} \mid \mathrm{rO}_{2}$ electrodes, OER is more rapid when the molar
\end{abstract}


percent of $\mathrm{PtO}_{y}$ meets the following condition: $0<x \leq 80$. This study also showed that the mixed coupled electrodes are more electrocatalytically active for OER than either $\mathrm{PtO}_{y}$ or $\mathrm{IrO}_{2}$ in these two media.

\section{Keywords}

Platinum oxide, iridium dioxide, mixed Pt-Ir oxide, oxygen evolution, Tafel slope, electrocatalytic activity

\section{Introduction}

Currently, climate changes and energy shortage are some of the greatest challenges for humanity [1-3]. Increasing carbon dioxide $\left(\mathrm{CO}_{2}\right)$ levels in the atmosphere cause severe issues such as global warming, energy security, and sustainability. These issues stimulated researchers to find new clean technologies that are high in efficiency and low in cost [4]. To fulfill this goal without destroying the environment, alternative methods of energy generation, conversion, and storage need to be employed [5-8]. As a sustainable and environmentally friendly alternative, water electrolysis combined with renewable electricity sources, such as wind and solar power, is expected to provide a practical solution. However, the major drawback of technologies such as solar or wind energy is that they cannot function continuously. Thus, renewable energy from water splitting by the electrochemical route is considered as one of the important techniques to provide a solution for climate change and energy shortage. The overall water splitting reaction includes the hydrogen evolution reaction (HER) and oxygen evolution reaction (OER). To realize the practical and sustainable application of electrocatalytic hydrogen/oxygen evolution reactions (HER/OER), an efficient, durable, and economical electrocatalyst is demanded triggering the reaction with minimal overpotential and fast kinetics [9-11].

According to the literature, the high-performance electrocatalysts are mainly based on noble metals such as for example, platinum [12,13]. From the cost perspective, however, it is highly desirable to develop electrocatalysts based on metal oxides.

The most usually targeted OER electrocatalyst oxides are iridium oxide $\left(\mathrm{IrO}_{2}\right)$ and ruthenium oxide $\left(\mathrm{RuO}_{2}\right)$ [14-16]. Ruthenium oxide exhibits several interesting properties, and has the advantages of high conductivity and good electrochemical reversibility [17-19]. However, the ruthenium oxide electrode is not applicable for long-term operations and dissolves during OER. Iridium oxide has attracted considerable attention due to its unique advantages including excellent chemical stability and sensitivity, impressive electrocatalytic activity, and sufficient electric conductivity [20-22]. Besides, the iridium oxide is known for its superb biocompatibility and longterm stability [23-27].

It was already found that when $\mathrm{IrO}_{2}$ is mixed with Pt oxide, Pt-Ir oxide shows enhanced electrocatalytic activity and rapid oxygen evolution reaction $[28,29]$. To further research about electrocatalytic properties of mixed $\mathrm{PtO}_{y}-\mathrm{IrO}_{2}$, it appears necessary to optimize the ratio of $\mathrm{PtO}_{\mathrm{y}}$ and $\mathrm{IrO}_{2}$ on this electrode. In the present work, the proportion of each element (Pt and Ir) of the mixed electrode has been varied and the influence of these variations on the kinetics of OER is studied. Mixed ${ }_{x}$ PtO $_{y^{-}(100-x)}$ IrO $_{2}$ electrodes $(x=0,10,20,30,40,50,60,70,80,90$ and 100) where $x$ represents the molar percent of $\mathrm{PtO}_{\mathrm{y}}$ precursor, have been prepared thermally at $450{ }^{\circ} \mathrm{C}$ and the kinetics of OER is followed on these electrodes in $0.1 \mathrm{M} \mathrm{KOH}$ and $0.1 \mathrm{M} \mathrm{HClO}_{4}$ media, respectively.

\section{Experiments}

Metallic supports (or substrates) of titanium plates of dimensions $16 \times 16 \times 0.5 \mathrm{~mm}$ were used. These supports were pretreated by sandblasting and rinsing to remove all the impurities and to 
increase the roughness which improves adhesion of the deposit. The surfaces were degreased and cleaned with isopropanol, followed by rinsing with distilled water. Precursors of $\mathrm{H}_{2} \mathrm{PtCl}_{6} \times 6 \mathrm{H}_{2} \mathrm{O}$ (Fluka, $99 \%$ ), and $\mathrm{H}_{2} \mathrm{IrCl}_{6} \times \mathrm{H}_{2} \mathrm{O}$ (Fluka, $99 \%$ ) were applied by brushes to the surfaces of the pretreated electrodes. These precursors were diluted in isopropanol (Fluka, $99.5 \%$ ). Two precursor solutions of $\mathrm{H}_{2} \mathrm{PtCl}_{6} \times \mathrm{H}_{2} \mathrm{O}$ and $\mathrm{H}_{2} \mathrm{ICl}_{6} \times \mathrm{H}_{2} \mathrm{O}$ were prepared separately at $23.30 \mathrm{~g} / \mathrm{L}$ and $23.25 \mathrm{~g} / \mathrm{L}$, respectively. Then, mixtures of these two solutions were prepared, respecting the proportions by moles number of $\mathrm{PtO}_{y}$ and $\mathrm{IrO}_{2}$ for the coupled mixed electrodes. The concentrations of precursors in the mixture which served for the preparation of the mixed ${ }_{x} \mathrm{PtO}_{y^{-}(100-\mathrm{x})} \mid \mathrm{rO}_{2}$ electrodes are grouped in Table 1. The solvent of the deposit was evaporated by baking in the oven at $80^{\circ} \mathrm{C}$ for $10 \mathrm{~min}$. Then the deposit underwent thermolysis in the furnace for $15 \mathrm{~min}$ at $450^{\circ} \mathrm{C}$. Several layers of deposit were thus produced before being calcined in the furnace at $450{ }^{\circ} \mathrm{C}$ for one hour. The mixed coupled ${ }_{x} \mathrm{PtO}_{y^{-}}(100-$ $\left.{ }_{x}\right) \mathrm{IO}_{2}$ electrodes $(\mathrm{x}=0,10,20,30,40,50,60,70,80,90$ or 100$)$ were prepared by this method, where $\mathrm{x}$ is referred to the molar percent of $\mathrm{PtO}_{\mathrm{y}}$ precursor. For the mixed electrodes, a mixture of different percent molars of the corresponding precursors was used. The deposit loading was about $5 \mathrm{~g} \mathrm{~m}^{-2}$ on each titanium substrate.

Table 1. Concentrations of $\mathrm{H}_{2} \mathrm{PtCl}_{6} \times \mathrm{H}_{2} \mathrm{O}$ and $\mathrm{H}_{2} \mathrm{IrCl}_{6} \times \mathrm{H}_{2} \mathrm{O}$ in the mixed coupled precursors used for preparation of mixed electrodes

\begin{tabular}{|c|c|c|}
\hline Electrodes & Concentration of $\mathrm{H}_{2} \mathrm{PtCl}_{6} \times \mathrm{H}_{2} \mathrm{O}, \mathrm{M}$ & Concentration of $\mathrm{H}_{2} \mid \mathrm{rCl}_{6} \times \mathrm{H}_{2} \mathrm{O}, \mathrm{M}$ \\
\hline${ }_{10} \mathrm{PtO}_{\mathrm{y}}-90 \mathrm{IrO} 2$ & 0.0045 & 0.0405 \\
\hline${ }_{20} \mathrm{PtO}_{\mathrm{y}^{-} 80} \mathrm{IrO} \mathrm{O}_{2}$ & 0.0090 & 0.0360 \\
\hline${ }_{30} \mathrm{PtO}_{\mathrm{y}-70} \mathrm{IrO}_{2}$ & 0.0135 & 0.0315 \\
\hline${ }_{40} \mathrm{PtO}_{\mathrm{y}^{-} 60} \mathrm{IrO} \mathrm{H}_{2}$ & 0.0180 & 0.0270 \\
\hline${ }_{50} \mathrm{PtO}_{y^{-}-50} \mathrm{IrO}_{2}$ & 0.0225 & 0.0225 \\
\hline${ }_{60} \mathrm{PtO}_{\mathrm{y}-40} \mathrm{IrO}_{2}$ & 0.0270 & 0.0180 \\
\hline${ }_{70} \mathrm{PtO}_{\mathrm{y}^{-}-30} \mathrm{IrO} \mathrm{O}_{2}$ & 0.0315 & 0.0135 \\
\hline${ }_{80} \mathrm{PtO}_{\mathrm{y}-20} \mathrm{IrO}_{2}$ & 0.0360 & 0.0090 \\
\hline${ }_{90} \mathrm{PtO}_{\mathrm{y}^{-}-10} \mathrm{IrO}_{2}$ & 0.0405 & 0.0045 \\
\hline
\end{tabular}

High-resolution images of the prepared electrode surfaces were realized by scanning electron microscopy (SEM, ZEISS, SUPRA 40VP). The crystalline structure was examined by X-ray diffraction (XRD) using a Siemens equipment with a Cu cathode. The XPS analysis was carried out with a Kratos Axis-Ultra Spectrometer using a monochromatic Al Ka X-Ray source, operated at $15 \mathrm{kV}$, and a pass energy of $20 \mathrm{eV}$.

The electrochemical measurements (cyclic and linear sweep voltammetry) were carried out using a conventional three-electrode electrochemical cell and Autolab PGStat 20 (Ecochemie). The prepared ${ }_{x} \mathrm{PtO}_{y^{-}(100-x)} \mid \mathrm{rO}_{2}$ electrodes, having geometric surface area of $0.785 \mathrm{~cm}^{2}$, served as the working electrodes (WE). The reference electrode (RE) was a saturated calomel electrode (SCE), mounted in a Luggin capillary and placed close to WE by a distance of $1 \mathrm{~mm}$. The counter-electrode (CE) was the spiral platinum wire, having the area at least hundred times larger than WE. All potential values in this manuscript are given against the reversible hydrogen electrode (RHE) using the following relation:

$$
E_{\mathrm{RHE}}=E_{\mathrm{SCE}}+0.059 \mathrm{pH}+0.244 \mathrm{~V}
$$

All electrochemical experiments were made at the ambient temperature of $25^{\circ} \mathrm{C}$. 


\section{Results and discussion}

\section{Physical characterization of prepared electrodes}

The prepared electrodes were analyzed by scanning electron microscopy. The surface micrographs of $\mathrm{IrO}_{2},{ }_{40} \mathrm{PtO}_{y^{-} 60} \mathrm{IO}_{2},{ }_{70} \mathrm{PtO}_{y^{-} 30} \mathrm{IrO}_{2}$, and $\mathrm{PtO}_{y}$ electrodes are presented in Figure 1 . The micrograph of pure $\mathrm{IrO}_{2}$ in Figure 1a shows superimposed layers of iridium dioxide, cracks and some pores, what is in accordance with the literature [24]. The cracks observed on the surface of pure $\mathrm{IrO}_{2}$ occurred during the cooling of the deposit due to the mechanical stresses produced by the difference in the coefficients of thermal expansion of the substrate and the deposit. In Figure $1 b$, SEM image of the electrode containing ${ }_{40} \mathrm{PtO}_{\mathrm{y}}-60 \mathrm{IrO}_{2}$ shows that the surface of this deposit appears more continuous and the cracks are narrower in comparison with pure $\mathrm{IrO}_{2}$. Also, some small $\mathrm{Pt}$ crystals dispersed on the surface of the deposit can be observed in Figure 1b. SEM image of the deposit containing ${ }_{70} \mathrm{PtO}_{y^{-} 30} \mathrm{IrO}_{2}$ is presented in Figure $1 \mathrm{c}$, showing a porous and very rough surface with almost non-existent cracks. At this stage, the layer of the deposit resembles that of $\mathrm{PtO}_{\mathrm{y}}$ [25]. On $\mathrm{PtO}_{y}$ electrode surface shown in Figure $1 \mathrm{~d}$, there are no cracks but the grains are strongly bonded to each other, thus showing the porous and rough nature of the deposited $\mathrm{PtO}_{\mathrm{y}}$. These observations indicate that when the molar percentage of $\mathrm{PtO}_{\mathrm{y}}$ in the deposit increases, the surface structure of the deposit tends to be more like that of $\mathrm{PtO}_{\mathrm{y}}$.
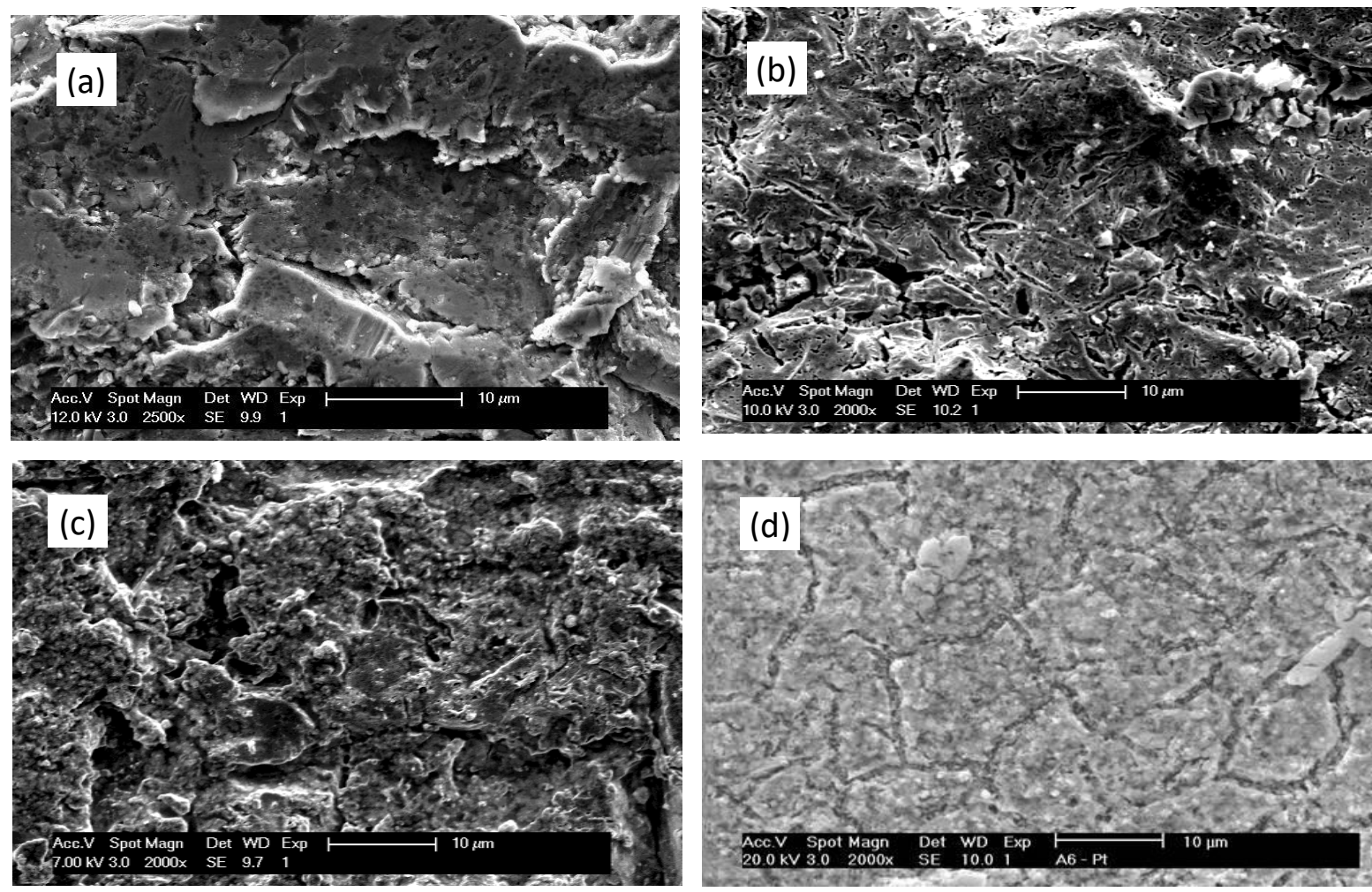

Figure 1. Scanning electron micrographs of $\mathrm{IrO}_{2}(a),{ }_{40} \mathrm{PtO}_{y^{-} 60} \mathrm{IrO}_{2}(b),{ }_{70} \mathrm{PtO}_{y^{-} 30} \mathrm{IrO}_{2}(\mathrm{c})$ and $\mathrm{PtO}_{y}(\mathrm{~d})$

XPS spectra of $\mathrm{PtO}_{y},{ }_{50} \mathrm{PtO}_{4}-50 \mathrm{IrO}_{2}$ and $\mathrm{IrO}_{2}$ electrodes are presented in Figure 2 . On the XPS spectrum of $\mathrm{PtO}_{y}$, one can notice the presence of three intense peaks at 70, 312 and $335 \mathrm{eV}$, which all characterize platinum presence on titanium. Carbon is also present with a peak observed at $286 \mathrm{eV}$ at all presented electrodes. Presence of carbon could be due to the poisoning of the measuring device, isopropanol used in the precursor preparations, and/or contamination in the oven used to prepare the electrodes. Two very close peaks are observed at 218 and $224 \mathrm{eV}$. These two peaks characterize the presence of platinum oxide. In the XPS spectrum of the mixed electrode 
${ }_{50} \mathrm{PtO}_{y^{-5} 50} \mathrm{rO}_{2}$ in addition to platinum peaks observed at 70,312 and $335 \mathrm{eV}$, there are some new peaks at 61, 296 and $494 \mathrm{eV}$. These three new peaks also exist in XPS spectrum of pure iridium oxide, approving the presence of iridium oxide in the mixed electrode.

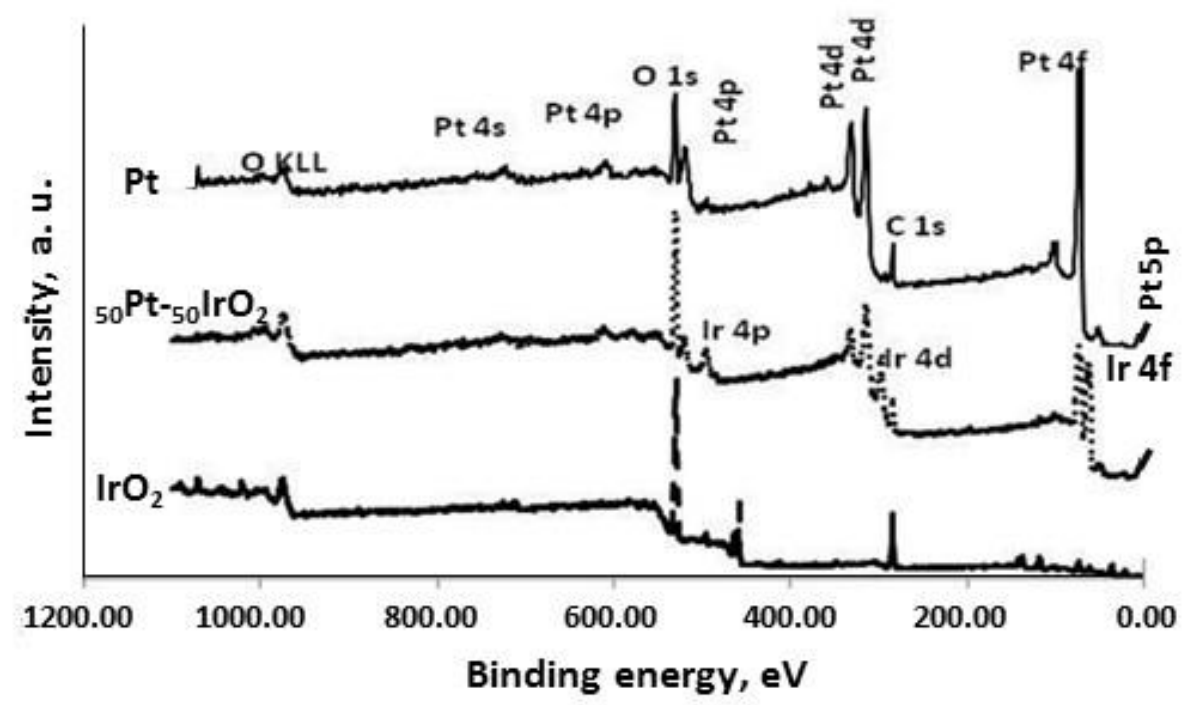

Figure 2. XPS spectra of $\mathrm{PtO}_{y},{ }_{50} \mathrm{PtO}_{y-50} \mathrm{IrO}_{2}$ and $\mathrm{IrO}_{2}$.

The XRD spectrum of $\mathrm{PtO}_{\mathrm{y}}$ presented in Figure 3 provides more details on the bulk structure of the platinum coating. The XRD pattern of $\mathrm{PtO}_{\mathrm{y}}$ shows two peaks at $2 \theta=40$ and $68^{\circ}$, which are assigned to the metallic Pt (JCPDS $\mathrm{N}^{\circ} 4-802$ ). The peaks located at 35 and $63^{\circ}$ correspond to $\mathrm{PtO}_{2}$ (JCPDS N $\left.\mathrm{N}^{\circ} 38-1355\right)$. The peaks located at $2 \theta=40$ and $53^{\circ}$ could be assigned to $\mathrm{Ti}$ [29]. Those XRD results indicate that the coating of $\mathrm{PtO}_{\mathrm{y}}$ is a mixture of metallic $\mathrm{Pt}$ and $\mathrm{PtO}_{2}$. In other words, the deposit is a mixture of Pt with zero-valence and its oxidized form, what also confirms the XPS results of $\mathrm{PtO}_{\mathrm{y}}$. Generally, both XPS and XRD results reveal that platinum present at the titanium surface exists in different oxidized states.

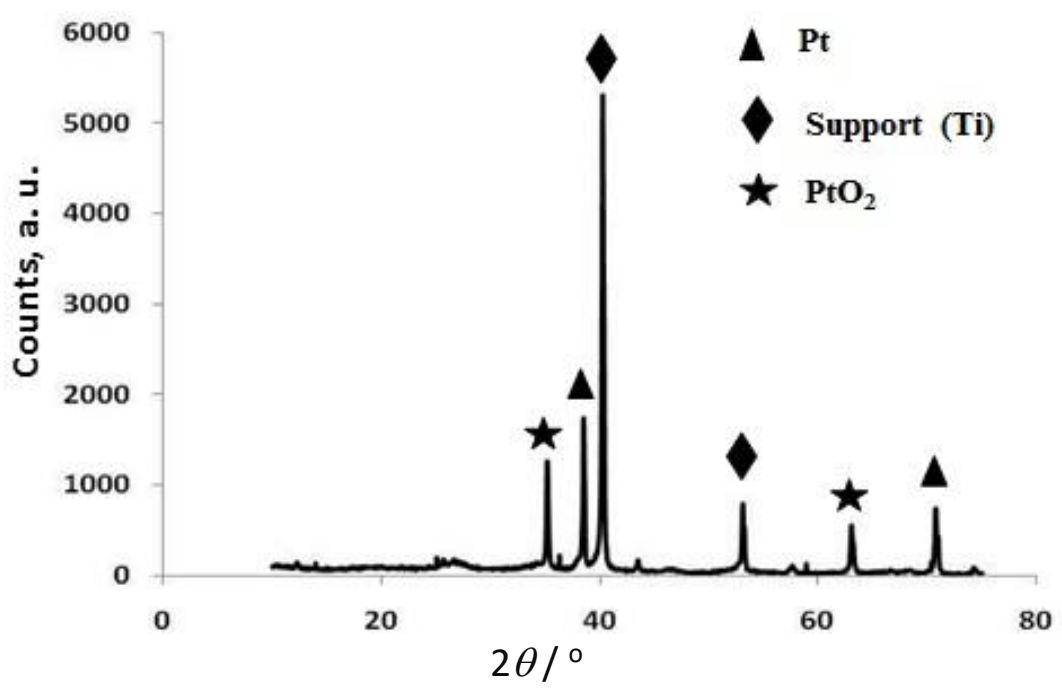

Figure 3. XRD spectrum of PtO

Electrochemical characterization of prepared electrodes with ferri/ferrocyanide redox couple

Figure 4a shows the cyclic voltammograms of the mixed ${ }_{60} \mathrm{PtO}_{y^{-}} \mathrm{IrO}_{2}$ electrode in $1 \mathrm{M} \mathrm{KOH}$, containing different concentrations of potassium ferri-ferrocyanide couple (1-100 mM). These voltammograms showed oxidation peaks in the forward potential scans and reduction peaks in the 
reverse potential scans. There is an increase in the current density of both peaks with increase of the concentration of potassium ferri-ferrocyanide couple. The current densities of the oxidation and reduction peaks were plotted as a function of the concentration of potassium ferri-ferrocyanide for ${ }_{10} \mathrm{PtO}_{y^{-} 90} \mathrm{IrO}_{2},{ }_{50} \mathrm{PtO}_{\mathrm{y}^{-} 50} \mathrm{IrO}_{2}$, and ${ }_{90} \mathrm{PtO}_{\mathrm{y}^{-10}} \mathrm{IrO}_{2}$ electrodes, and presented in Figures $4 \mathrm{~b}$ and $4 \mathrm{c}$. The obtained curves are straight lines that pass through the origin of the coordinate system. Note that similar results were obtained with other mixed electrodes studied here (curves not shown). The equations of the lines make it possible to determine the anode $\left(D_{\mathrm{a}}\right)$ and cathode $\left(D_{\mathrm{c}}\right)$ diffusion coefficients, using the following equation [30,31]:

$j_{\mathrm{p}}=2.6910^{5} \mathrm{n}^{3 / 2} A D^{1 / 2} C v^{1 / 2}$

In eq. (2), $j_{\mathrm{p}}$ is peak current density, $n$ is number of exchanged electrons, $A$ is geometric surface area, $C$ is concentration of reaction species, $D$ is their diffusion coefficient, and $v$ is scan rate.
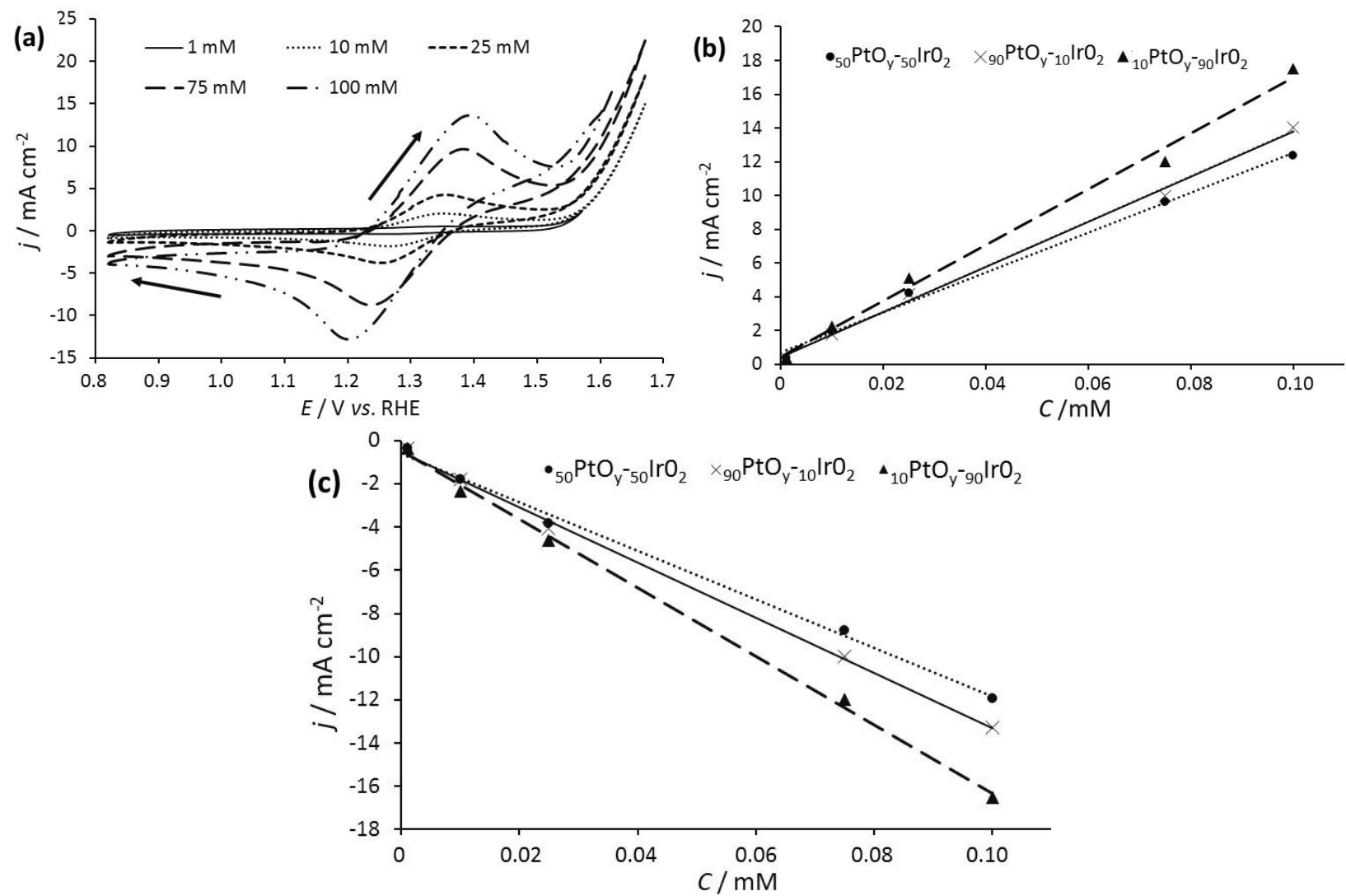

Figure 4: Cyclic voltammetry of mixed ${ }_{60} \mathrm{PtO}_{y^{-}-40 \mathrm{IrO}}$ electrode in $1 \mathrm{M} \mathrm{KOH}$ containing different concentrations of ferri-ferrocyanide redox couple at $20 \mathrm{mV} \mathrm{s}^{-1}$ (a), anodic peak current densities (b) and cathodic peak current densities (c) against concentrations of $\left[\mathrm{Fe}(\mathrm{CN})_{6}\right]^{3-} /\left[\mathrm{Fe}(\mathrm{CN})_{6}\right]^{4-}$ at mixed ${ }_{10} \mathrm{PtO}_{y^{-}}{ }_{90} / \mathrm{rO}_{2},{ }_{50} \mathrm{PtO}_{y^{-5}} \mathrm{IrO}_{2}$ and ${ }_{90} \mathrm{PtO}_{y^{-1}} \mathrm{IrO}_{2}$ electrodes.

The values of diffusion coefficients of ferri/ferrocyanide couple listed in Table 2 were determined by eq. (2) with $n=1$, and are of the same order of magnitude as those from the literature [33]. The certain difference observed between the values determined in this work and literature data could be linked to the use of the geometric surface and not the real surface of the electrode in the calculation. It is clear from Table 2 that $D$ values are somewhat lower for mixed ${ }_{x} \mathrm{PtO}_{y^{-}(100-x)} \mid \mathrm{rO}_{2}$ electrodes than those obtained on pure $\mathrm{IrO}_{2}$ and $\mathrm{PtO}_{y}$.

The ratios of the absolute value of the anode and cathode peak current densities are also shown in Table 2. A value close to 1 was obtained for each electrode. These results confirm an almost reversible behavior of the potassium ferri-ferrocyanide couple on all here studied electrodes. 
Table 2: Kinetic parameters of ferri/ferrocyanide redox reaction in $1 \mathrm{M} \mathrm{KOH}$ at ${ }_{x} \mathrm{PtO}_{y^{-}(100-x)} I_{\text {IrO }}$ electrodes

\begin{tabular}{|c|c|c|c|}
\hline Electrodes & $\left|j_{\mathrm{Pa}} / j_{\mathrm{Pc}}\right|$ & $D_{\mathrm{a}} / 10^{-6} \mathrm{~cm}^{2} \mathrm{~s}^{-1}$ & $D_{\mathrm{c}} / 10^{-6} \mathrm{~cm}^{2} \mathrm{~s}^{-1}$ \\
\hline $\mathrm{PtO}_{\mathrm{y}}$ & 1.03 & 9.43 & 9.77 \\
\hline${ }_{90} \mathrm{PtO}_{\mathrm{y}-10 \mathrm{IrO}}$ & 1.00 & 5.19 & 6.11 \\
\hline${ }_{80} \mathrm{PtO}_{\mathrm{y}-20} \mathrm{IrO}_{2}$ & 1.01 & 5.24 & 5.88 \\
\hline${ }_{70} \mathrm{PtO}_{\mathrm{y}-30} \mathrm{IrO} \mathrm{O}_{2}$ & 0.99 & 3.27 & 5.02 \\
\hline${ }_{60} \mathrm{PtO}_{\mathrm{y}}-40 \mathrm{IrO}{ }_{2}$ & 1.02 & 3.62 & 5.04 \\
\hline${ }_{50} \mathrm{PtO}_{y}-50 \mathrm{lrO}{ }_{2}$ & 1.04 & 4.57 & 6.33 \\
\hline${ }_{40} \mathrm{PtO}_{\mathrm{y}}-60 \mathrm{IrO}{ }_{2}$ & 1.00 & 2.70 & 4.60 \\
\hline${ }_{30} \mathrm{PtO}_{\mathrm{y}}-70 \mathrm{IrO}{ }_{2}$ & 0.99 & 2.50 & 4.29 \\
\hline${ }_{20} \mathrm{PtO}_{\mathrm{y}-80} \mathrm{IrO}{ }_{2}$ & 1.01 & 4.47 & 5.20 \\
\hline${ }_{10} \mathrm{PtO}_{\mathrm{y}-90} \mathrm{lrO}{ }_{2}$ & 1.03 & 4.37 & 3.65 \\
\hline $\mathrm{IrO}_{2}$ & 1.06 & 12.29 & 12.92 \\
\hline
\end{tabular}

Electrochemical characterization of prepared electrodes in $\mathrm{KOH}$ medium

Figure 5a shows cyclic voltammograms of $\mathrm{PtO}_{y}$ and $\mathrm{IrO}_{2}$ in the basic medium $(0.1 \mathrm{M} \mathrm{KOH})$ in the oxide stability potential zone ( 0.77 to $1.47 \mathrm{~V}$ vs. $\mathrm{RHE}$ ). For pure $\mathrm{PtO}_{\mathrm{y}}$, a presence of some reduction current can be noticed from 0.77 to $0.91 \mathrm{~V}$ vs. RHE. This can be ascribed to the reduction of oxides formed in the forward potential scan [33] and also during the electrode calcination. A rectangular shape from 0.91 to $1.47 \mathrm{~V} / \mathrm{RHE}$ is characterized by an almost constant current density and found similar to that observed previously [29]. In comparison to $\mathrm{IrO}_{2}$ electrode, $\mathrm{PtO}_{\mathrm{y}}$ electrode has much lower voltammetric charge. At the other side, $\mathrm{IrO}_{2}$ electrode possesses very high voltammetric charge and its voltammetric response is generally characteristic for heat-prepared DSAs (dimensionally stable anodes) [29,35,36]. Much improved voltammetric charge of the pure $\mathrm{IrO}_{2}$ electrode can be associated with the pseudocapacitive reactions at $\mathrm{IrO}_{2}$ and also, due to the presence of cracks and pores that increased the number of electrode active sites at the surface [35]. Figure $5 \mathrm{~b}$ shows cyclic voltammograms of mixed ${ }_{\mathrm{x}} \mathrm{PtO}_{y^{-}(100-\mathrm{x})} \mid \mathrm{rO}_{2}$ electrodes in $0.1 \mathrm{M} \mathrm{KOH}$ medium from 0.77 to $1.47 \mathrm{~V} / \mathrm{RHE}$. The voltammograms of mixed electrodes have shapes similar to $\mathrm{PtO}_{y}$, indicating that $\mathrm{PtO}_{\mathrm{y}}$ is present on all the prepared mixed electrodes. However, the voltammetric charges of these electrodes are higher than that of $\mathrm{PtO}_{\mathrm{y}}$. This increase in the voltammetric charge is due to the presence of $\mathrm{IrO}_{2}$ on the surface of mixed electrodes. At mole percentages of $\mathrm{PtO}_{y}$ greater than $50 \%$, the voltammetric charge is lower than that of $\mathrm{IrO}_{2}$ but still greater than that of $\mathrm{PtO}_{\mathrm{y}}$. For mole percentages of $\mathrm{PtO}_{\mathrm{y}}$ less than $50 \%$, the voltammetric charge is higher than that of $\mathrm{PtO}_{\mathrm{y}}$ and $\mathrm{IrO}_{2}$. The highest voltammetric charge is observed for $\mathrm{PtO}_{y}$ with mol percentage of $40 \%$. The high voltammetric charge of mixed electrodes shows the increase in active sites due to the presence of both $\mathrm{PtO}_{\mathrm{y}}$ and $\mathrm{IrO}_{2}$.
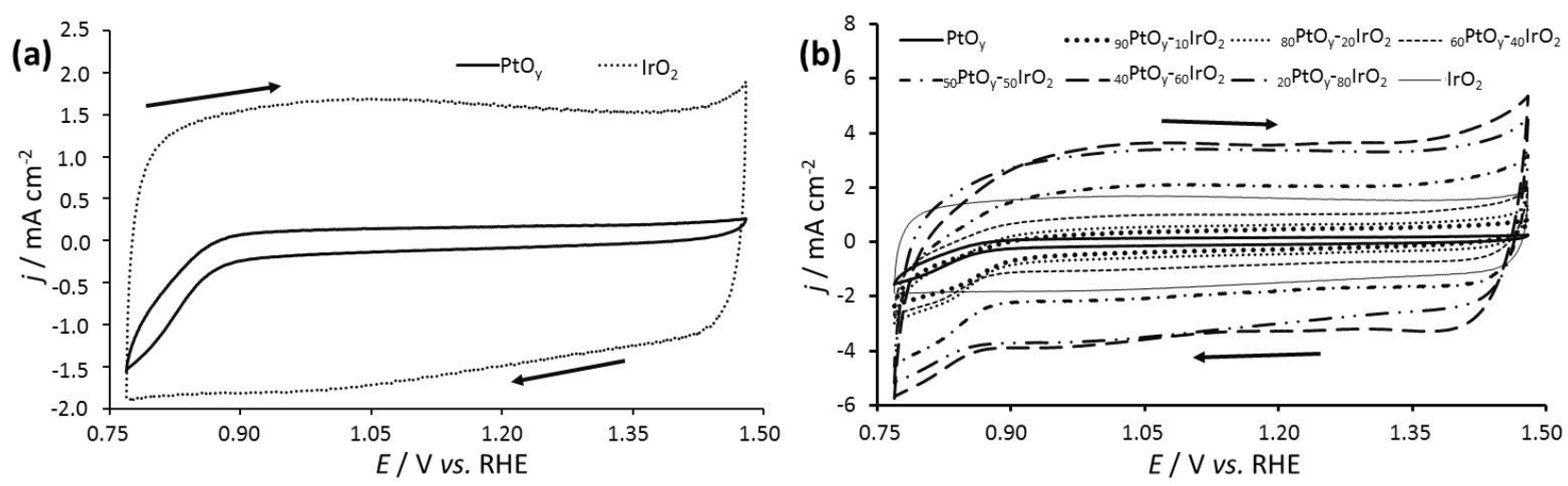

Figure 5. Cyclic voltammograms $\left(10 \mathrm{mV} \mathrm{s}^{-1}\right)$ in $0.1 \mathrm{M} \mathrm{KOH}$ of PtO$_{y}$ and $\mathrm{IrO}_{2}$ electrodes (a) and ${ }_{x} \mathrm{PtO}_{y^{-}(100-x)} / \mathrm{rO}_{2}$ electrodes (b). 
The studies were also carried out at the lower scan rate because, at a low scan rate, the system is in a quasi-stationary state. In Figure 6, the linear voltammograms obtained with different $\left.{ }_{x} \mathrm{PtO}_{y^{-}(100-x)}\right) \mathrm{rO}_{2}$ electrodes in the basic medium of $0.1 \mathrm{M} \mathrm{KOH}$ are presented. These voltammograms show that the potential at $j=1 \mathrm{~mA} \mathrm{~cm}^{-2}$ related to oxygen evolution varies from one electrode to another. The OER potential was also determined at $j=10 \mathrm{~mA} \mathrm{~cm}^{-2}$ for each electrode. The potential values of all prepared ${ }_{\mathrm{x}} \mathrm{PtO}_{\mathrm{y}^{-}(100-\mathrm{x})} \mathrm{IO}_{2}$ electrodes at these two current density values are presented in Table 3.

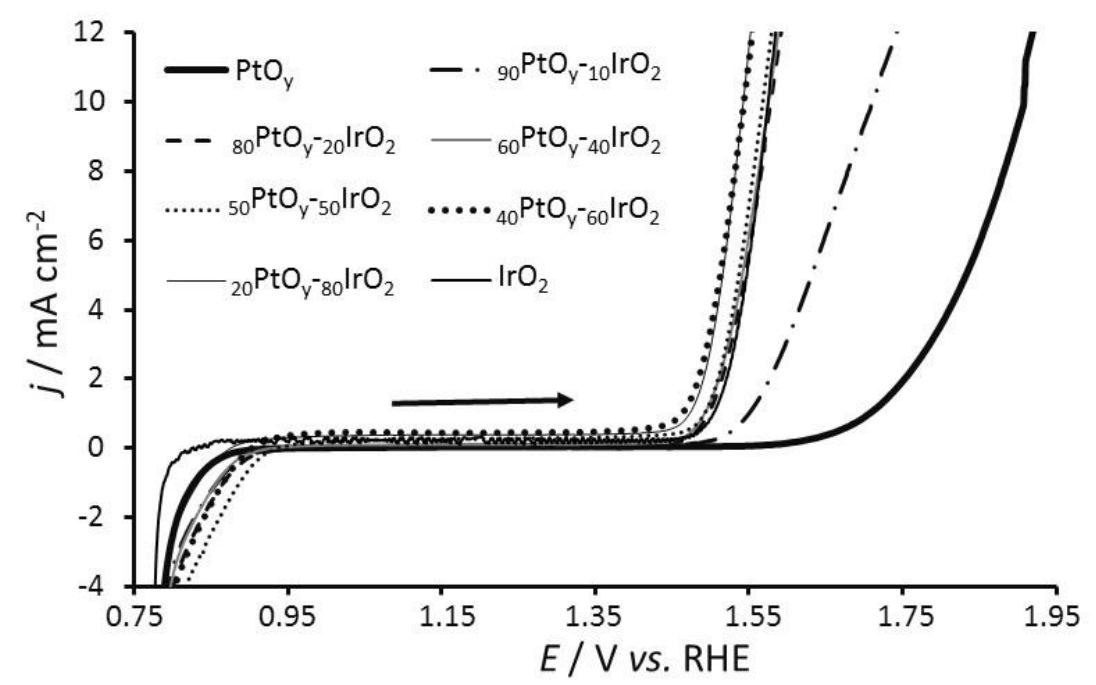

Figure 6. Linear voltammograms $\left(5 \mathrm{mV} \mathrm{s}^{-1}\right)$ of prepared electrodes in $0.1 \mathrm{M} \mathrm{KOH}$ medium

Table 3. Potentials of oxygen evolution reaction on various ${ }_{x} \mathrm{PtO}_{y^{-}(100-x)} / \mathrm{rO}_{2}$ electrodes in $0.1 \mathrm{M} \mathrm{KOH}$ at $j=1 \mathrm{~mA} \mathrm{~cm}^{-2}$ and $j=10 \mathrm{~mA} \mathrm{~cm}^{-2}$, scan rate $=5 \mathrm{mV} \mathrm{s}^{-1}$.

\begin{tabular}{|c|c|c|}
\hline Electrode & $E / \mathrm{V} v s . \operatorname{RHE}\left(j=1 \mathrm{~mA} \mathrm{~cm}^{-2}\right)$ & $E / \mathrm{V} v s . \operatorname{RHE}\left(j=10 \mathrm{~mA} \mathrm{~cm}^{-2}\right)$ \\
\hline $\mathrm{PtO}_{\mathrm{y}}$ & 1.679 & 1.908 \\
\hline${ }_{90} \mathrm{PtO}_{y^{-1}-10 \mathrm{IrO}_{2}}$ & 1.521 & 1.710 \\
\hline${ }_{80} \mathrm{PtO}_{y-20} \mathrm{IrO}_{2}$ & 1.488 & 1.578 \\
\hline${ }_{70} \mathrm{PtO}_{y-30} \mathrm{IrO}_{2}$ & 1.473 & 1.571 \\
\hline${ }_{60} \mathrm{PtO}_{\mathrm{y}-40} \mathrm{IrO}_{2}$ & 1.470 & 1.576 \\
\hline $50 \mathrm{PtO}_{y-50 \mathrm{IrO}}$ & 1.468 & 1.568 \\
\hline${ }_{40} \mathrm{PtO}_{y-60 I \mathrm{IO}_{2}}$ & 1.460 & 1.544 \\
\hline${ }_{30} \mathrm{PtO}_{y^{-}-70 \mathrm{IrO}}$ & 1.453 & 1.531 \\
\hline${ }_{20} \mathrm{PtO}_{\mathrm{y}-80} \mathrm{IrO}_{2}$ & 1.464 & 1.543 \\
\hline${ }_{10} \mathrm{PtO}_{y-90} \mathrm{IrO}_{2}$ & 1.467 & 1.557 \\
\hline $\mathrm{IrO}_{2}$ & 1.489 & 1.576 \\
\hline
\end{tabular}

Data in Table 3 show that OER potentials for ${ }_{x} \mathrm{PtO}_{y^{-}(100-x)} \mid \mathrm{rO}_{2}$ electrodes determined at $j=1 \mathrm{~mA} \mathrm{~cm}^{-}$ 2 and $j=10 \mathrm{~mA} \mathrm{~cm}^{-2}$ vary in a similar way. The highest potential values observed at any current density for $\mathrm{PtO}_{y}$ electrode suggest that it is less electrocatalytically active for OER than other electrodes in the basic medium. Also, it seems that ${ }_{90} \mathrm{PtO}_{y^{-1}-10 \mathrm{IO}_{2}}$ electrode is more electrocatalytically active than $\mathrm{PtO}_{\mathrm{y}}$, but less than $\mathrm{IrO}_{2}$ and other mixed electrodes. On the other hand, the electrodes with $\mathrm{PtO}_{\mathrm{y}}$ percentage lower or equal to $80 \%$ have a potential related to OER close but less than pure $\mathrm{IrO}_{2}$. It is clear that the coupling of $\mathrm{PtO}_{y}$ with $\mathrm{IrO}_{2}$ has improved electrocatalytic activity of the electrode. The electrodes which have $\mathrm{PtO}_{y}$ percentage lower or equal to $80 \%$ are the most electrocatalytically active for the oxygen evolution in the basic medium.

The Tafel slope of OER on an electrode can be abnormally high, especially within a high potential domain. According to Kapalka et al. [37], the increase of the Tafel slope is due to the ohmic drop. 
The ohmic drop between the anode and the cathode is due to the geometry of the cell, solution conductivity, presence of bubbles in solution, and accumulation of gas bubbles produced on the surface of the electrode (blockage of the surface) [38,39]. Here, the ohmic drop corrections of the measured polarization curves were carried out according to the method already described in the literature $[28,29]$. Briefly speaking, the overpotential $(\eta / \mathrm{V})$ observed in the experiment can be defined by

$$
\eta=a+b \ln j+j R
$$

where $a$ / V is Tafel constant, $b / \mathrm{V} \mathrm{dec}-1$ is Tafel slope, $j / \mathrm{A} \mathrm{cm}^{-2}$ is current density and $R / \Omega \mathrm{cm}^{-2}$ is the total area-specific, uncompensated resistance of the system, assumed to be constant. The derivative of eq. (3) concerning current density, results in eq. (4) from which $b$ and $R$ can be easily obtained by plotting $\mathrm{d} \eta / \mathrm{d} j$ as a function of $1 / j$.

$$
\mathrm{d} \eta / \mathrm{d} j=(b / j)+R
$$

The estimation of $R$ allows correcting the experimental overpotential by subtracting the ohmic drop $j R$ according to the following equation:

$$
\eta_{\text {corr }}=\eta-j R
$$

where $\eta_{\text {corr }}$ stands for the corrected overpotential.

During the calculations, the derivatives $\mathrm{d} \eta / \mathrm{d} j$ were replaced by their finite elements $\Delta \eta / \Delta j$ estimated from each pair of consecutive experimental points.

After correcting the ohmic drop for each electrode in the electrolyte used, the Tafel slope lines were determined from the corrected $E$ vs. log $j$ dependences that are for some $\left.{ }_{x} \mathrm{PtO}_{y^{-}(100-x)}\right) \mathrm{rO}_{2}$ electrodes presented in Figure 7a.
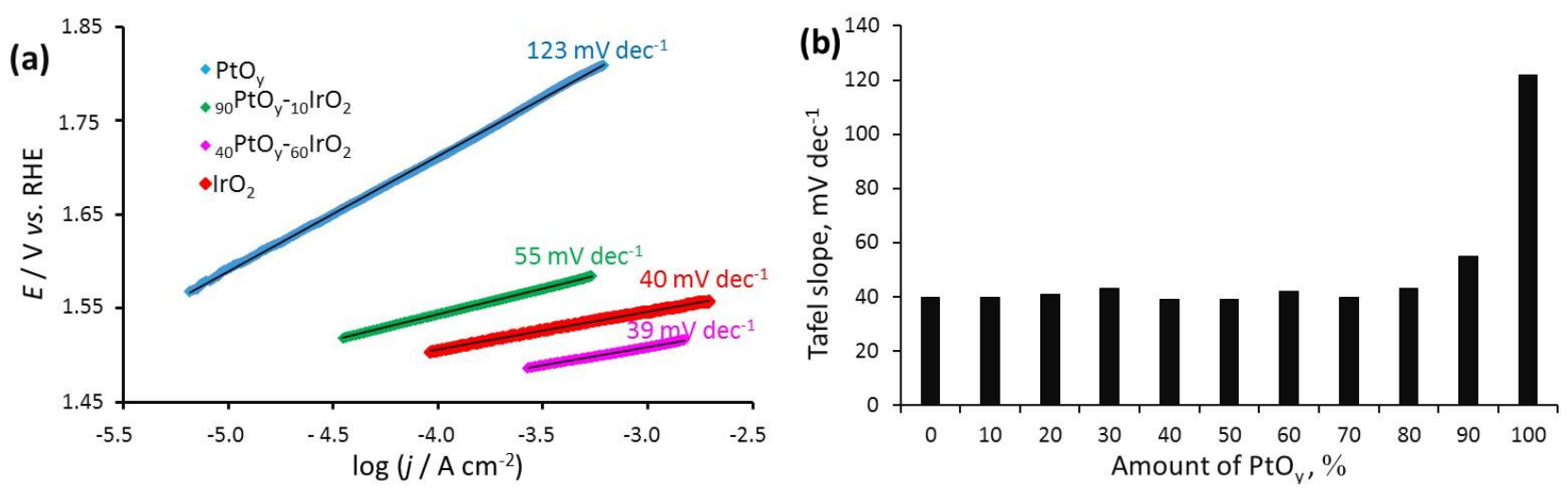

Figure 7. Tafel lines (a) and Tafel slopes (b) of different ${ }_{x} \mathrm{PtO}_{y^{-}(100-\mathrm{x})} / \mathrm{rO}_{2}$ electrodes in $0.1 \mathrm{M} \mathrm{KOH}$.

Note that Tafel slopes vary from electrode to electrode, suggesting that the kinetics of OER varies from one electrode to another Thus, it can be seen from Figure 7a that the Tafel slope of pure $\mathrm{IrO}_{2}$ electrode is $40 \mathrm{mV} \mathrm{dec} \mathrm{c}^{-1}$. According to Figure $7 \mathrm{~b}$, Tafel slope remains almost constant at $40 \mathrm{mV} \mathrm{dec}^{-1}$ for all mixed electrodes which have $\mathrm{PtO}_{\mathrm{y}}$ percentage lower or equal to $80 \%$. This result indicates that $\mathrm{OER}$ at $\mathrm{IrO}_{2}$ and all these mixed electrodes proceeds practically with the same kinetics. At the other side, Tafel slopes of 55 and $122 \mathrm{mV} \mathrm{dec}^{-1}$ were respectively obtained for ${ }_{90} \mathrm{PtO}_{\mathrm{y}}-10 \mathrm{IrO}_{2}$ and $\mathrm{PtO}_{\mathrm{y}}$ electrodes. These results suggest that the electrodes which have the voltammetric response close to $\mathrm{PtO}_{\mathrm{y}}$ have also high Tafel slope similar to $\mathrm{PtO}_{\mathrm{y}}$. This is the case for electrodes whose surfaces are rich in $\mathrm{PtO}_{\mathrm{y}}$. Also, when the surface is dominated by $\mathrm{IrO}_{2}$, the Tafel slopes tend towards that of pure $\mathrm{IrO}_{2}$.

Generally, the values of the obtained Tafel slopes suggest that the kinetics of OER on mixed electrodes is faster on the electrodes having the percentage of $\mathrm{PtO}_{\mathrm{y}}$ lower or equal to $80 \%$ than on the electrodes with the percentage of $\mathrm{PtO}_{y}$ higher than $80 \%$. 
The OER mechanism in the basic media is taken from the literature on mixed $\mathrm{PtO}_{\mathrm{y}}$ and $\mathrm{IrO}_{2}$ electrodes [32], and described by following four steps

$$
\begin{aligned}
& \mathrm{S}+\mathrm{OH}^{-} \rightarrow \mathrm{SOH}+\mathrm{e}^{-} \\
& \mathrm{SOH}+\mathrm{OH}^{-} \rightarrow \mathrm{SO}^{-}+\mathrm{H}_{2} \mathrm{O} \\
& \mathrm{SO}^{-} \rightarrow \mathrm{SO}+\mathrm{e}^{-} \\
& 2 \mathrm{SO} \rightarrow 2 \mathrm{~S}+\mathrm{O}_{2}
\end{aligned}
$$

where $\mathrm{S}$ stands for electrode active sites, while $\mathrm{OH}, \mathrm{O}^{-}$and $\mathrm{O}$ represent adsorbed intermediates.

The mechanism described by eqs. (6-9) predicts the Tafel slope of $120 \mathrm{mV} \mathrm{dec}^{-1}$ when step

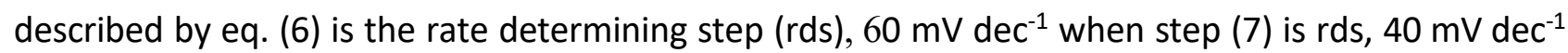
when step (8) is rds, and $15 \mathrm{mV} \mathrm{dec}^{-1}$ when step described by eq. (9) is rds.

Tafel slopes presented in Figure $7 \mathrm{~b}$ suggest that mixed ${ }_{x} \mathrm{PtO}_{y^{-}(100-x)} \mid \mathrm{rO}_{2}$ electrodes have probably the same reaction pathway for OER, but different rate determining steps. For $\mathrm{PtO}_{\mathrm{y}}$ anode, the first step described by eq. (6) can be considered as the rate determining step, because the observed Tafel slope is close to $120 \mathrm{mV} \mathrm{dec}^{-1}$. On the pure $\mathrm{IrO}_{2}$ and the anodes with $\mathrm{PtO}_{\mathrm{y}}$ percentage less or equal to $80 \%$, the observed Tafel slope is $40 \mathrm{mV} \mathrm{dec}^{-1}$, indicating that the step described by eq. (8) could be considered as the rate determining step. For the electrode containing $90 \%$ of $\mathrm{PtO}_{y}$, the second step described by eq. (7) will be considered as the rate determining step, because its Tafel slope was found close to $60 \mathrm{mV} \mathrm{dec}{ }^{-1}$.

\section{Electrochemical characterization of prepared electrodes in perchloric acid medium}

The oxygen evolution has also been studied in an acid medium. The linear voltammograms of mixed ${ }_{x} \mathrm{PtO}_{y^{-}(100-x)} \mid \mathrm{rO}_{2}$ electrodes in $0.1 \mathrm{M} \mathrm{HClO}_{4}$, recorded in a quasi-stationary manner are presented in Figure 8.

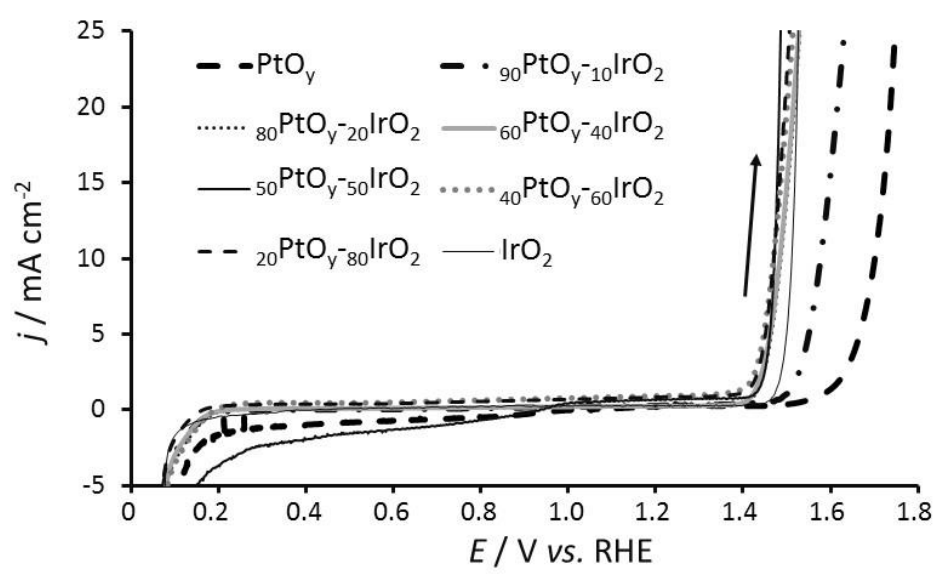

Figure 8. Linear voltammetry $\left(5 \mathrm{mV} \mathrm{s}^{-1}\right)$ of ${ }_{x} \mathrm{PtO}_{y^{-}(100-x)} \mathrm{IrO}_{2}$ electrodes in $0.1 \mathrm{M} \mathrm{HClO}_{4}$

Figure 8 shows that the onset potential related to the oxygen evolution (the potential of the sharp current increase) varies from one electrode to another but is the highest for $\mathrm{PtO}_{\mathrm{y}}$ electrode. The potential values at $j=1 \mathrm{~mA} \mathrm{~cm}{ }^{-2}$ and $j=10 \mathrm{~mA} \mathrm{~cm}^{-2}$ related to OER were determined for all ${ }_{x} \mathrm{PtO}_{y^{-}(100-\mathrm{x})} \mathrm{IrO}_{2}$ electrodes and the obtained values are represented in Table 4.

Data in Table 4 show that potential values of OER vary from one electrode to another similarly and regardless of the current density. $\mathrm{PtO}_{\mathrm{y}}$ electrode has the highest potential related to oxygen evolution, suggesting that $\mathrm{PtO}_{\mathrm{y}}$ is the least electrocatalytically active electrode for OER in an acid medium. Except for the electrode which contains $90 \% \mathrm{PtO}_{y}$, the mixed ${ }_{\mathrm{x}} \mathrm{PtO}_{y^{-}(100-\mathrm{x})} \mid \mathrm{rO}_{2}$ electrodes have lower onset potentials related to OER than either pure $\mathrm{PtO}_{\mathrm{y}}$ or pure $\mathrm{IrO}_{2}$. This pointed out that the mixed Pt-Ir oxide electrode in an acid medium is generally more electrocatalytically active for 
$\mathrm{O}_{2}$ evolution than its pure components. These results are fully consistent with those observed for OER in the basic medium.

Table 4. Potentials of oxygen evolution reaction on various ${ }_{x} \mathrm{PtO}_{y^{-}(100-\mathrm{x})} / \mathrm{rO}_{2}$ electrodes in $0.1 \mathrm{M} \mathrm{HClO}_{4}$ at $j=1 \mathrm{~mA} \mathrm{~cm}^{-2}$ and $j=10 \mathrm{~mA} \mathrm{~cm}^{-2}$ and scan rate $=5 \mathrm{mV} \mathrm{s}^{-1}$

\begin{tabular}{|c|c|c|}
\hline Electrode & $E / V$ vs. RHE $\left(j=1 \mathrm{~mA} \mathrm{~cm}^{-2}\right)$ & $E / \mathrm{V} v s . \operatorname{RHE}\left(j=10 \mathrm{~mA} \mathrm{~cm}^{-2}\right)$ \\
\hline PtOy & 1.571 & 1.714 \\
\hline $90 \mathrm{PtO}_{y-10} \mathrm{IrO}_{2}$ & 1.470 & 1.587 \\
\hline $80 \mathrm{PtO}_{y-20} \mathrm{IrO}_{2}$ & 1.434 & 1.479 \\
\hline $70 \mathrm{PtO}_{y-30} \mathrm{IrO}_{2}$ & 1.428 & 1.475 \\
\hline${ }_{60} \mathrm{PtO}_{y-40} \mathrm{IrO}_{2}$ & 1.430 & 1.475 \\
\hline${ }_{50} \mathrm{PtO}_{y-50} \mathrm{IrO}_{2}$ & 1.438 & 1.475 \\
\hline${ }_{40} \mathrm{PtO}_{y^{-60}} \mathrm{IrO}_{2}$ & 1.431 & 1.458 \\
\hline${ }_{30} \mathrm{PtO}_{y^{-}-70 \mathrm{IrO}}$ & 1.424 & 1.454 \\
\hline${ }_{20} \mathrm{PtO}_{y-80} \mathrm{IOO}_{2}$ & 1.429 & 1.461 \\
\hline${ }_{10} \mathrm{PtO}_{y-90} \mathrm{IrO}_{2}$ & 1.441 & 1.481 \\
\hline $\mathrm{IrO}_{2}$ & 1.450 & 1.514 \\
\hline
\end{tabular}

The Tafel slopes for OER in $0.1 \mathrm{M} \mathrm{HClO}_{4}$ were determined for all studied $\left.{ }_{x} \mathrm{PtO}_{y^{-}(100-\mathrm{x})}\right) \mathrm{rO}_{2}$ electrodes. As shown in Figure 9a, plotting of the corrected $E$ vs. log $j$ gave straight lines in the Tafel region. The particular values of Tafel slopes for all studied ${ }_{x} \mathrm{PtO}_{y^{-}(100-x)} \mid \mathrm{rO}_{2}$ electrodes are recorded in Figure $9 \mathrm{~b}$.
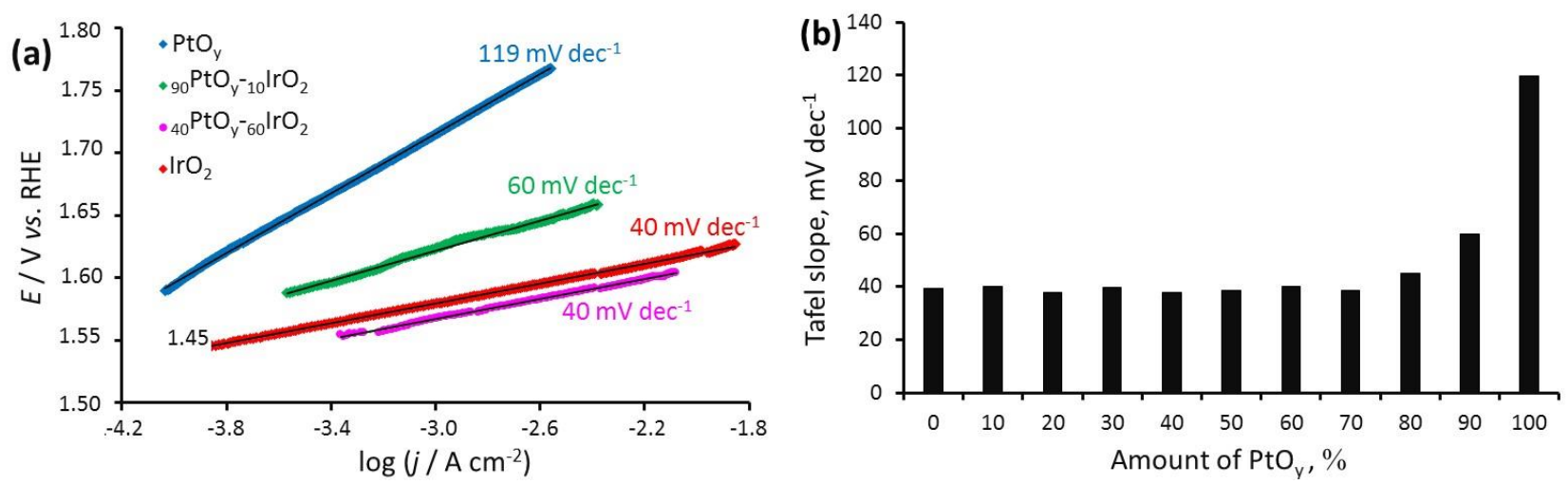

Figure 9. Tafel lines (a) and Tafel slopes (b) of different ${ }_{x} \mathrm{PtO}_{y^{-}(100-x)} \mathrm{IrO}_{2}$ electrodes in $0.1 \mathrm{M} \mathrm{HClO}_{4}$ at $5 \mathrm{mV} \mathrm{s}^{-1}$

Tafel slope of $120 \mathrm{mV} \mathrm{dec}^{-1}$ was obtained for pure $\mathrm{PtO}_{\mathrm{y}}$, while $60 \mathrm{mV} \mathrm{dec}^{-1}$ was obtained for the mixed electrode with $90 \%$ of $\mathrm{PtO}_{\mathrm{y}}$. The other mixed electrodes and pure $\mathrm{IrO}_{2}$ gave values of $40 \mathrm{mV} \mathrm{dec}^{-1}$. All these values obtained in the acid medium $\left(0.1 \mathrm{M} \mathrm{HClO}_{4}\right)$ are almost identical to those obtained in the basic medium $(0.1 \mathrm{M} \mathrm{KOH})$. Also, the Tafel slopes show that the oxygen evolution reaction in the acidic and basic medium is faster on the electrodes which have a percentage in $\mathrm{PtO}_{\mathrm{y}}$ lower or equal to $80 \%$ than on the electrodes which have a percentage in $\mathrm{PtO}_{\mathrm{y}}$ higher than $80 \%$.

The obtained Tafel slopes, together with the literature results $[27,29,40]$ point towards the following mechanism of OER on the prepared electrodes in an acid medium:

$$
\begin{aligned}
& \mathrm{S}+\mathrm{H}_{2} \mathrm{O} \rightarrow \mathrm{S}-\mathrm{OH}+\mathrm{H}^{+}+\mathrm{e}^{-} \\
& \mathrm{S}-\mathrm{OH} \rightarrow \mathrm{SO}+\mathrm{H}^{+}+\mathrm{e}^{-} \\
& 2 \mathrm{SO} \rightarrow 2 \mathrm{~S}+\mathrm{O}_{2}
\end{aligned}
$$

where $\mathrm{S}$ stands for electrode active sites, while $\mathrm{OH}$ and $\mathrm{O}$ represent adsorbed intermediates.

The mechanism described by eqs. (10-12) predicts the Tafel slope of $120 \mathrm{mV} \mathrm{dec}^{-1}$ if the first step described by eq. (10) is the rate determining step ( $\mathrm{rds}$ ), $40 \mathrm{mV} \mathrm{dec}^{-1}$ if the second step described by eq. (11) is rds, and $30 \mathrm{mV} \mathrm{dec}^{-1}$ if the third step described by eq. (12) is rds. 
For OER on $\mathrm{PtO}_{y}$ in $\mathrm{HClO}_{4}$ medium, the rate determining step is the first step described by eq. (10), because the Tafel slope is $120 \mathrm{mV} \mathrm{dec}{ }^{-1}$. For the pure $\mathrm{IrO}_{2}$ electrode and the mixed ${ }_{x} \mathrm{PtO}_{y^{-}(100-x)} \mathrm{IrO}_{2}$ electrodes except that with $90 \% \mathrm{PtO}_{y}$, the rate determining step is the second step described by eq. (11), because their Tafel slopes are very close to $40 \mathrm{mV} \mathrm{dec}^{-1}$. With the platinumiridium dioxide coupling with a proportion of $90 \% \mathrm{PtO}_{\mathrm{y}}$, however, the Tafel slope is $60 \mathrm{mV} \mathrm{dec}^{-1}$. This specific value is between that obtained for pure $\mathrm{PtO}_{\mathrm{y}}\left(120 \mathrm{mV} \mathrm{dec}^{-1}\right)$ and $\mathrm{IrO}_{2}\left(39 \mathrm{mV} \mathrm{dec}^{-1}\right)$, but closer to $\mathrm{IrO}_{2}$ than $\mathrm{PtO}_{\mathrm{y}}$. This result is in agreement with the voltammogram for ${ }_{90} \mathrm{PtO}_{\mathrm{y}^{-10}} \mathrm{IrO}_{2}$ electrode that is closer to $\mathrm{IrO}_{2}$ than $\mathrm{PtO}_{y}$.

Generally, Tafel slopes of mixed ${ }_{x} \mathrm{PtO}_{y^{-}(100-x)} \mid \mathrm{rO}_{2}$ electrodes are close to that of $\mathrm{IrO}_{2}$ and it is just $\mathrm{IrO}_{2}$ which determines the oxygen evolution rate. The rate determining step is similar to that obtained with

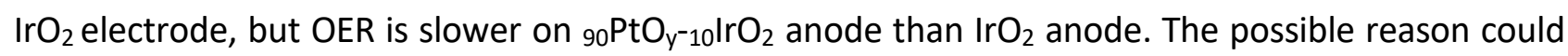
be the mixed kinetics due to the adsorption of unstable species such as $\mathrm{S}-\mathrm{OH}^{*}$ (equations 13a and 13b), or the synergistic effect of $\mathrm{PtO}_{y}$ and $\mathrm{IrO}_{2}$ [22]. The mechanism of OER involving eq. (13) instead eq. (10) accounts for possible surface chemical rearrangements. Therefore, the elemental step described by eq. (13b) probably controls the overall rate of OER $[41,42]$.

$$
\begin{aligned}
& \mathrm{S}+\mathrm{H}_{2} \mathrm{O} \rightarrow \mathrm{S}-\mathrm{OH}^{*}+\mathrm{H}^{+}+\mathrm{e}^{-} \\
& \mathrm{S}-\mathrm{OH}^{*} \rightarrow \mathrm{S}-\mathrm{OH}
\end{aligned}
$$

In each specific solution, $\mathrm{PtO}_{y}, \mathrm{IrO}_{2}$ and mixed coupled ${ }_{\mathrm{x}} \mathrm{PtO}_{y^{-}(100-\mathrm{x})} \mid \mathrm{rO}_{2}$ electrodes studied here, generally follow the same oxygen evolution reaction pathway described by equations (6-9) or (10-13), but with different rate determining steps. Note that OER reaction pathways described by equations (6-9) and equations (10-12) are generally known as the oxide decomposition path and the electrochemical oxide path, respectively [43].

The electrodes with molar percentage of $\mathrm{PtO}_{y}$ lower or equal to $80 \%$ have the lowest Tafel slope values. This shows that the kinetics of OER is faster for these electrodes than for the electrodes which have $\mathrm{PtO}_{y}$ percentage greater than $80 \%$. This result is in agreement with the voltammetric curves where the onset potential related to oxygen evolution reaction on these electrodes is lower than that obtained with the electrodes with $\mathrm{PtO}_{\mathrm{y}}$ content greater than $80 \% \mathrm{~mol}$. It is clear from these results that the electrodes which have a voltammetric behavior close to that of iridium oxide have faster OER kinetics than the electrodes which have the $\mathrm{PtO}_{\mathrm{y}}$ content greater than $80 \%$ mol. When the mixed oxide surface is dominated by certain metal oxide, the slope of Tafel tends towards that oxide. These observations agree with the scanning electron micrographs because on the electrodes having content less or equal to $80 \%$ there are prominent pores and cracks on these electrodes. This has increased the number of active sites, hence the rapid kinetics of oxygen production.

\section{Conclusions}

The physical (SEM, XPS and XRD) and electrochemical (cyclic and linear voltametries) characterizations of mixed coupled deposits of $\left.{ }_{x} \mathrm{PtO}_{y^{-}(100-x)}\right) \mathrm{rO}_{2}$ with different molar percent of $\mathrm{PtO}_{y}$ precursor $(x=0,10,20,30,40,50,60,70,80,90$ and 100) produced thermally on titanium supports, have shown rather different properties.

Presence of $\mathrm{Pt}$ in different oxidation states $\left(\mathrm{Pt}\right.$ and $\left.\mathrm{PtO}_{2}\right)$ and presence of pure $\mathrm{IrO}_{2}$ is indicated for mixed coupled ${ }_{x} \mathrm{PtO}_{y^{-}(100-x)} \mid \mathrm{rO}_{2}$ deposits, while their surface morphology was changed from the highly cracked and porous surface characteristic for pure $\operatorname{IrO}_{2}(x=0)$ to more continuous and much less cracked $\mathrm{PtO}_{\mathrm{y}}(\mathrm{x}=100)$.

All prepared mixed coupled ${ }_{x} \mathrm{PtO}_{y^{-}(100-x)} \mid \mathrm{rO}_{2}$ electrodes showed the metallic character by supporting perfectly the reversible ferri/ferrocyanide reaction taken as the redox probe. 
Voltammetric charges measured in the oxide region of potentials for all mixed coupled $\left.{ }_{x} \mathrm{PtO}_{y^{-}(100-x)}\right) \mathrm{rO}_{2}$ electrodes in $0.1 \mathrm{M} \mathrm{KOH}$ were found higher than for pure $\mathrm{PtO}_{\mathrm{y}}$. For mixed electrodes having the mol percentage of $\mathrm{PtO}_{\mathrm{y}}$ equal or less than $50 \%(\mathrm{x} \leq 50)$, the voltammetric charge is found even higher than for pure $\mathrm{IrO}_{2}$. The highest voltammetric charge was observed for the mixed of ${ }_{40} \mathrm{PtO}_{\mathrm{y}^{-} 60} \mathrm{IrO}_{2}$ electrode, i.e. the electrode having $\mathrm{PtO}_{\mathrm{y}}$ mol percentage of $40 \%(x=40)$. This could be ascribed to the increase of electrochemical surface area of the electrode due to the presence of both $\mathrm{PtO}_{\mathrm{y}}$ and $\mathrm{IrO}_{2}$.

In either basic $(0.1 \mathrm{M} \mathrm{KOH})$ or acid $\left(0.1 \mathrm{M} \mathrm{HClO}_{4}\right)$ media, all mixed $\left.{ }_{x} \mathrm{PtO}_{y^{-}(100-x)}\right) \mathrm{rO}_{2}$ electrodes were found more electrocatalytically active for oxygen evolution reaction (OER) than pure $\mathrm{PtO}_{\mathrm{y}}$ electrode. The mixed electrode having mol percentage of $\mathrm{PtO}_{y}$ equal or lower than $80 \%(x \leq 80)$ showed similar, or for $(x \leq 40)$ even better electrocatalytic activity for OER than pure $1 \mathrm{rO}_{2}$. Tafel slopes of mixed ${ }_{x} \mathrm{PtO}_{y^{-}(100-\mathrm{x})} \mid \mathrm{rO}_{2}$ electrodes obtained from linear voltammograms corrected for ohmic drops, suggest faster OER on coupled mixed ${ }_{x} \mathrm{PtO}_{y^{-}(100-x)} \mid \mathrm{rO}_{2}$ electrodes having $(x \leq 80)$ than pure $\mathrm{PtO}_{\mathrm{y}}$. This suggests that just presence of $\mathrm{IrO}_{2}$ determines high oxygen evolution rate at coupled mixed ${ }_{x} \mathrm{PtO}_{y^{-}(100-x)} \mid \mathrm{rO}_{2}$ electrodes.

\section{References}

[1] D. Gielen, F. Boshell, D. Saygin, Nature Materials 15 (2016) 117-120.

[2] A. Bielecki, S. Ernst, W. Skrodzka, I. Wojnicki, Research 27 (2020) 11506-11530.

[3] B. A. Olanipekun, N. O. Adelakun, International Journal of Engineering Trends Technology, 68(1) (2020) 64-67.

[4] S. Chu, A. Majumdar, Nature 488 (2012) 294-303.

[5] M. K. Hubbert, Science 109 (1949) 103-109.

[6] R. E. White, R. Grossman, Science 328 (2010) 5975173. https://doi.org/10.1126/science.328.5975.173-a.

[7] T. Martin, Nature 538 (2016). https://doi.org/10.1038/538171c

[8] J. Tollefson, Nature 521 (2015) 16-17. https://doi.org/10.1038/521016a

[9] J. Mahmood, F. Li, S. Jung, M.S. Okyay, I. Ahmad, S. Kim, N. Park, H.Y. Jeong, J. Baek, Nature Nanotechnology 12(5) (2017) 441-446.

[10] S. J. Gutić, A. S. Dobrota, E. Fako, N. V. Skorodumova, N. López, I. A. Pašti, Catalysts 10(3) (2020) 290.

[11] P. J. Rheinlander, J. Herranz, J. Durst, H. A. Gasteiger, Journal of the Electrochemical Society, 161(14) (2014) F1448-F1457.

[12] Y. Xu, B. Zhang, Chemical Society Reviews 43 (2014) 2439-2450.

[13] H.-J. Yin, J.-H. Zhou, Y.-W. Zhang, Inorganic Chemistry Frontiers 6 (2019) 2582-2618. https://doi.org/$10.1039 / C 9 Q 100689 \mathrm{C}$

[14] Z. Ma, Y. Zhang, S. Liu, W. Xu, L. Wu, Y.-C. Hsieh, P. Liu, Y. Zhu, K. Sasaki, J. N. Renner, K. E. Ayers, R. R. Adzic, J. X. Wang, Journal of Electroanalytical Chemistry 819(15) (2018) 296-305. https://doi.org/10.1016/j.jelechem.2017.10.062

[15] K. V. Sankar, R. Attias, Y. Tsur, Electrochemistry Communications 110 (2020) 106641. https://doi.org/10.1016/j.elecom.2019.106641

[16] S-A Park, K.-S. Kim, Y.-T. Kim, ACS Energy Letters 3(5) (2018) 1110-1115. https://doi.org/10.1021/acsenergylett.8b00368

[17] D. Majumdar, Material Science Research India 15(1) (2018) 30-40.

[18] S. Hadži-Jordanov, H. Angerstein-Kozlowska, M. Vuković, B. E. Conway, Journal of the Electrochemical Society 125 (1978) 1471-1480.

[19] V. Birss, B. E. Conway, H. Angerstein-Kozlowska, Journal of the Electrochemical Society 131 (1984) 1502-1510.

[20] D. Böhm, M. Beetz, M. Schuster, K. Peters, A. G. Hufnagel, M. Döblinger, B. Böller, T. Bein, D. Fattakhova-Rohlfing, Advanced Functional Materials 30 (2020) 1906670.

[21] S. Li, C. Xi, Y.-Z. Jin, D. Wu, J.-Q. Wang, T. Liu, H.-B. Wang, C.-K. Dong, H. Liu, S. A. Kulinich, X.-W. Du, ACS Energy Letters 4(8) (2019) 1823-1829. 
[22] J. Cheng, J. Yang, S. Kitano, G. Juhasz, M. Higashi, M. Sadakiyo, K. Kato, S. Yoshioka, T. Sugiyama, M. Yamauchi, N. Nakashima, ACS Catalysis 9(8) (2019) 6974-6986.

[23] J. Lee, B. Jeong, J. D. Ocon, Current Applied Physics 13 (2013) 309-321.

[24] L. A. G. Pohan, L. Ouattara, La Revue Ivoirienne des Sciences et Technologie 19 (2012) 12-25.

[25] J.-M. Hu, J.-Q. Zhang, C.-N. Cao, International Journal of Hydrogen Energy 29 (2004) 791-797.

[26] O. Kambire, F. T. A. Appia, L. Ouattara, La Revue Ivoirienne des Sciences et Technologie 25 (2015) 2133.

[27] A. L. G. Pohan, L. Ouattara, K. H. Kondro, O. Kambiré, A. Trokourey, European Journal of Scientific Research 94(1) (2013) 96-108.

[28] O. Kambire, L. A. G. Pohan, F. T. A. Appia, C. Q.-M. Gnamba, K. H. Kondro, L. Ouattara, Journal of Electrochemical Science and Engineering 5(2) (2015) 79-91.

[29] A. L. G. Pohan, L. Ouattara, K. H. Kondro, O. Kambiré, A. Trokourey, European Journal of Scientific Research 94(1) (2013) 96-108.

[30] B. P. Hambly, J. B. Sheppard, B. D. Pendley, E. Lindner, Electroanalysis 30 (2018) 681-689.

[31] H. Kahlert, U. Retter, H. Lohse, K. Siegler, F. Scholz, Journal of Physical Chemistry B 102(44) (1998) 8757-8765.

[32] A. J. Bard, L. R. Faulkner, Electrochemical Methods: Fundamentals and Applications, $2^{\text {nd }}$ Edition, Wiley, 2001.

[33] R. P. Janek, W. R. Fawcett, A. Ulman, Langmuir 14(11) (1998) 3011-3018.

[34] O. Kambire, L. A. G. Pohan, F. T. A. Appia, C. Q.-M. Gnamba, K. H. Kondro, L. Ouattara, Journal of Electrochemical Science and Engineering 5(2) (2015) 79-91.

[35] T. A. F. Lassali, S. C. De Castro, J. F. C. Boodts, Electrochimica Acta 43 (16-17) (1998) 2515-2525.

[36] K. H. Kondro, L. Ouattara, A. Trokourey, Y. Bokra, Bulletin of the Chemical Society of Ethiopia 22(1) (2008) 125-134.

[37] A. Kapałka, G. Fóti, C. Comninellis, Electrochemistry Communications 10(4) (2008) 607-610.

[38] N. Katsuki, E. Takahashi, M. Toyoda, T. Kurosu, M. lida, S. Wakita, Y. Nishiki, T. Shimamune, Journal of the Electrochemical Society 145(7) (1998) 2358-2362

[39] G. H. Kelsall, Journal of Applied Electrochemistry 14(2) (1984) 177-186

[40] O. Kambire, L. A. G. Pohan, F. T. A. Appia, L. Ouattara, International Journal of Pure and Applied Science \& Technology 27(1) (2015) 27-43.

[41] B. M. Jović, U.Č. Lačnjevac, V.D. Jović, N.V. Krstajić, Journal of Electroanalytical Chemistry 754 (2015) 100-108.

[42] B. M. Jović, U. Č. Lačnjevac, V. D. Jović, L. Gajić-Krstajić, J. Kovač, D. Poleti, N. V. Krstajić, International Journal of Hydrogen Energy 41 (2016) 20502-20514.

[43] S. Trasatti, in: Encyclopedia of Electrochemical Power Sources, $1^{\text {st }}$ Edition, J. Garche, C. Dyer, P. Moseley, Z. Ogumi, D. Rand, B. Scrosati (Eds.), Elsevier Science, Amsterdam, Vol. 2, 2009, pp. 49-55.

(C)2020 by the authors; licensee IAPC, Zagreb, Croatia. This article is an open-access article distributed under the terms and conditions of the Creative Commons Attribution license (https://creativecommons.org/licenses/by/4.0/) 